\title{
Laparoscopic Pyeloplasty, Our Experience of Initial Fifty Two Cases
}

\author{
Laparoskopik Piyeloplasti, İlk Elli İki Olgu Deneyimimiz
}

\author{
iD Lokesh Sharma, iD Nisar Ahmed, [iD Mahakshit Bhat, iD Aayush Khetrapal, iD Rajeev Mathur, iD Ram Gopal Yadav
}

NIMS University, National Institute of Medical Sciences, Jaipur, Rajasthan, India

\section{What's known on the subject? and What does the study add?}

Open pyeloplasty is still considered to be gold standard for management of PUJ obstruction. Laparoscopy has provided similar results as in open surgery in many published series but with decreased morbidity. Only concern in lap is difficult suturing, which can be overcome by applying proper technique of spatulation and suturing. In this study we are presenting our initial experience of lap pyeloplasty and we found that lap pyeloplasty is safe, minimally invasive and viable alternative to open pyeloplasty for management of pelviureteric junction.

\begin{abstract}
Objective: With the increasing popularity of minimally-invasive surgery, laparoscopic pyeloplasty has become a staple in the armamentarium of urologists. However, the surgery has a steep learning curve and longer operative time. In this study, we aimed to evaluate the results of initial 53 cases of laparoscopic dismembered pyeloplasty in our institute.

Materials and Methods: A total 52 of patients with pelvi-ureteric junction (PUJ) obstruction, 30 male and 22 female, with the mean age of 23.5 years were managed by transperitoneal laparoscopic dismembered pyeloplasty. The patients were placed in full lateral position and surgery was done using a minimum of three ports, retrograde pyelography was done in all; initial access was done by using a Veress needle. The ureter was spatulated first, first suture taken and then the PUJ was dismembered to avoid rotation of the ureter. Antegrade DJ stenting was done in all patients and one drain was left in the retroperitoneum after surgery. DJ stent was removed six weeks after surgery.

Results: Fifty two patients were managed by dismembered pyeloplasty. Six patients required preoperative urinary diversion. Intrarenal pelvis was seen in seven, crossing vessel in ten, high insertion of ureter in six and associated calculus in five patients. Conversion to open surgery was required in six patients. Initially, the operative time was more than three hours but after sufficient experience of 25 cases, it reduced drastically and in last 28 cases, the mean operative time was 123 minutes, with shortest time reported 97 minutes. Reintervention was required in eight patients and overall success rate was $87 \%$.

Conclusion: Laparoscopic pyeloplasty is a safe, minimally-invasive and viable alternative to open pyeloplasty for the management of PUJ obstruction. Keywords: Laparoscopy, Pyeloplasty, PUJ, Obstruction, Dismembered
\end{abstract}

$0 ̈ z$

Amaç: Minimal invaziv cerrahinin artan popularitesiyle birlikte, Laparoskopik Piyeloplasti ürologların temel aracı haline gelmiş̧ir. Buna karşın cerrahi, dik bir öğrenme eğrisine ve daha uzun operasyon sürelerine sahiptir. Bu çalışmada, kliniğimizde laparoskopik parçalanmış piyeloplasti gerçekleştirilen ilk 52 olguya ait sonuçların değerlendirilmesi amaçlanmıştır.

Gereç ve Yöntem: Pelvi-üreterik bileşke (PÜE) darlığına sahip, 30 erkek ve 22 kadın olmak üzere yaş ortalaması 23,5 olan toplam 52 hastaya transperitoneal laparoskopik parçalanmış pyeloplasti uygulandı. Hastalar tam lateral pozisyona yerleştirildi ve en az üç port kullanılarak ameliyat yapıldı, hepsinde retrograd piyelografi yapıldı; ilk erişimde Veress iğnesi kullanıldı. Üreter ilk olarak spatüle edildi; önce sütür alındı ve daha sonra üreterin dönüşünü önlemek için PUJ parçalandı. Antegrad DJ stentleme bütün hastalara uygulandı ve operasyon sonrası retroperitonda bir diren bırakıldı. Operasyondan 6 hafta sonra DJ stent çıkarıldı.

Bulgular: Elli iki hasta parçalanmış piyeloplasti ile tedavi edildi. Altı hastaya ameliyat öncesi üriner diversiyon gerekti. Yedi hastada Intrarenal pelvis, 10 hastada damar geçişi, 6 hastada yüksek yerleşimli üreter ve 5 hastada ilişkili kalkül görülmüştür. Altı hastada açık cerrahiye dönülmesi gerekmiştir. Başlangıçta operasyon süresi 3 saatten daha uzunken, 25 olguda oluşan yeterli deneyim sonrası büyük ölçüde azalmıştır. Son 28 olgunun ortalama

Correspondence: Nisar Ahmed MD, NIMS University, National Institute of Medical Sciences, Jaipur, Rajasthan, India E-mail: drnisaruro@gmail.com ORCID-ID: orcid.org/0000-0002-6024-6016

Received: 07.11.2019 Accepted: 08.01.2020

Cite this article as: Sharma L, Ahmed N, Bhat M, Khetrapal A, Mathur R, Yadav RG. Laparoscopic Pyeloplasty, Our Experience of Initial Fifty Two Cases. J Urol Surg 2020;7(2):125-129.

๑Copyright 2020 by the Association of Urological Surgery / Journal of Urological Surgery published by Galenos Publishing House. 
operasyon süresi 123 dakika olup bunlar içinde en kısa süre ise 97 dakikadır. Sekiz hastada tekrar müdahale gerekirken, genel başarı oranı \%87'dir. Sonuç: Laparoskopik piyeloplasti; güvenilir, minimal invaziv ve PÜE darlık yönetiminde açık piyeloplasti yerine uygulanabilir alternatif bir yöntemdir. Anahtar Kelimeler: Laparoskopi, Piyeloplasti, PÜE, Darlık, Parçalanmış

\section{Introduction}

Management of pelvi-ureteric junction (PUJ) obstruction has always been challenging. Open pyeloplasty was first described by Trendelenburg in 1886 (1), and later on was modified and popularised by Anderson and Hynes, and since then open pyeloplasty has become the gold standard treatment for PUJ obstruction, with a long-term success rate of $>90 \%$ in many series $(2,3,4)$. As open surgery has its morbidity, endopyelotomy was introduced for the management of PUJ obstruction. Although the morbidity of open surgery can be avoided with endopyelotomy, the problem is the success rate, which has been reported to be $60-90 \%$ in many series $(5,6)$ with a follow-up of at least 6 months. A similar study compared correction rates between endoscopic and laproscopic approaches and established the supremacy of laproscopic approaches over endopyelotomy (7). Another problem with endopyelotomy is that it cannot be done for each and every case so, as a primary modality of treatment, it is not being done and not recommended nowadays. Then came laparoscopy and more recently robotics have been added for the management of PUJ obstruction. In comparison to open surgery, laparoscopy is less invasive, there is less pain during postoperative period, lesser requirement of analgesia, better recovery and quick resume normal activities. The only problem with laparoscopy is steep learning curve and longer operative time, mainly due to difficulty in spatulation and difficult intracorporeal suturing especially in early cases. Here, we present our initial cases of laparoscopic pyeloplasty done over a period of three years between June 2015 and August 2018.

\section{Metarials and Methods}

This is a retrospective study including a total of 52 patients, 30 males, 22 females, with the mean age of 23.5 years (range 4-55). To diagnose PUJ obstruction, ultrasonography, intravenous pyelogram, computed tomography (CT) urography and DTPA renal scan were done along with routine investigations. The indications for surgery were pain, stone, sepsis and decreased renal function. Transperitoneal laparoscopic dismembered pyeloplasty was done in all expect one where primary laparoscopic ureterocaly costomy was done due to intrarenal pelvis. A minimum of three and maximum of 4 or 5 ports were used. We used retrograde pyelography in all patients just before surgery and removed the ureteric catheter to keep the pelvis distended for subsequent easy and rapid dissection of the bowel. All patients were placed in the lateral position. All the crossing vessels were preserved except one in which clipping was required due to accidental tearing. Initially, we dismembered the PUJ completely before spatulation but found spatulation difficult, so later on modified our technique after reviewing the literature. We made pyelotomy proximal to the PUJ, holding one layer of the pelvis, advanced one blade of the scissor across the PUJ, directed it exactly over the lateral margin and then spatulated. With this technique, there is no chance of rotation of the ureter as it is still attached to the pelvis. After spatulation of the ureter the first suture was taken at the apex of the neo pelviureteric junction, and then on the posterior wall, all interrupted with a vicryl 3-0 or 4-0 with reverse cutting needle. After antegrade DJ stent placement, the anterior layer completed with interrupted sutures, and finally the pelvis was closed with continuous suture. Intrarenal pelvis was found in seven patients in whom we used continuous suturing. A drain was left after surgery. The Folley catheter was removed on postoperative day 2 and then drain, 48 hours after catheter removal depending of drain output. The DJ stent was removed after six weeks; the patients were followed monthly for the first three months, then every three months for the next one year and then every six months for three years. The patients were mainly followed by clinical assessment and by ultrasound, and intervened when required (Table 1).

\section{Statistical Analysis}

We used Microsoft Excel ${ }^{\circledR} 2016$ to tabulate the data and

\begin{tabular}{|l|l|}
\hline Table 1. Data of the patients & \\
\hline No of patients & 52 \\
\hline Male/female & $30 / 22$ \\
\hline Mean age & 23.5 years \\
\hline Malrotated & 2 \\
\hline Pre-op diversion & 6 \\
\hline Intrarenal pelvis & 7 \\
\hline Bilateral & 2 \\
\hline Crossing vessel & 10 \\
\hline High insertion & 6 \\
\hline Associated calculus & 5 \\
\hline Laterality & 32 left 20 right \\
\hline Transmesocolic & 3 \\
\hline Conversion to open & 4 \\
\hline Failed pyeloplasty & 7 \\
\hline
\end{tabular}


calculate the means of the age and operating time. We also calculated the average blood loss during the procedures using the same programme.

\section{Results}

Fifty two patients underwent transperitoneal laparoscopic pyeloplasty from 1 June 2015 to 31 August 2018. In six patients, urinary diversion was done before definitive surgery, DJ stent used in two and a nephrostomy tube was placed in four patients. Diversion was done due to pain, fever, pyonephrosis, and due to decreased renal parenchyma on ultrasound. Four patients required conversion to open surgery; in one, there were plenty of small calculi, in another, obstruction at PUJ looked doubtful and in two patients, there were dense adhesions (Table 2).

Intrarenal pelvis was seen in seven patients and only one patient required conversion to open surgery, in all other we could manage laparoscopically by doing continuous suturing. The mean blood loss was $67 \mathrm{~mL}$ and no patient required blood transfusion in the post-operative period. The mean operative time was 153 minutes in our series. No major complications were seen in the post-operative period. Three patients had prolonged urinary drainage, prolonged fever in two, post-operative ileus in one and two had port site infection. All patients were managed conservatively. The mean hospital stay was 5.3 days (range 4-9 days). A total of seven patients required reintervention, first patient of our series failed where we used V-loc suture due to lack of experience with intracorporeal suturing, in one child, in whom we used transmesocolic approach, the whole upper ureter was found to be necrosed, later on managed by ileal substitution of the ureter, although not at our center. These two patients were lost to follow-up. The remaining five patients were managed at our centre. One failed patient had prolonged drainage during the post-operative period. Two patients were managed by ureterocalycostomy, one by open and one by laparoscopic approach. In another three patients, redo open pyeloplasty was done. All these five patients are doing well after stent removal. The mean follow-up was 15 months in our series.

\begin{tabular}{|l|l|}
\hline Table 2. Intra-operative and post-operative variables \\
\hline Operative time & $153 \mathrm{~min} .(210-99 \mathrm{~min})$. \\
\hline Blood loss & $67 \mathrm{~mL}(50-105 \mathrm{~mL})$ \\
\hline Blood transfusion & Nil \\
\hline Fever & 2 \\
\hline Post-operative ileus & 1 \\
\hline Prolonged drainage & 3 \\
\hline Port site infection & 2 \\
\hline Hospital stay & 5.3 days (4-9 days) \\
\hline Reintervention & 7 \\
\hline Mean follow-up & 15 month (2-57 months) \\
\hline
\end{tabular}

\section{Discussion}

Open pyeloplasty has traditionally been considered the gold standard for the management of PUJ obstruction, which enjoys the long-term success rate of more than $90 \%$. But open surgery has its morbidity; big incision, being more invasive, more pain, more requirement of analgesia, longer recovery and long and ugly scar are the other drawbacks. To decrease the morbidity of open surgery, minimally-invasive approaches have been introduced. Endopyelotomy, although once popular, is not being recommended as the initial treatment of choice because of its low success rate in comparison to open surgery. The success rate with endopyelotomy is $60-90 \%$ in a follow-up period of 6 months or more (5). Availability and proven efficacy of laparoscopy in other areas prompted many urologists to use it for the management of PUJ obstruction. The first laparoscopy repair was reported by Schuessler et al. (8) and since then it is being used more and more frequently. Brooks et al. (7) established the superiority of laparoscopic approaches over endopyelotomy in a small study.

Here, we report our initial 52 cases of laparoscopic pyoloplasty in whom we did dismembered pyeloplasty whereas in one patient primary laparoscopic ureterocalycostomy was done because the pelvis was intrarenal. The mean operative time was 153 minutes in our series, and similar to other studies, operative time depends on the experience of the surgeon and it decreases drastically with increasing experience in laparoscopy (9). The main concern in laparoscopy is steep learning curve, and prolonged operative time, mainly because of difficulty in spatulation and intracorporeal suturing. Holding up the ureter and spatulation at the correct place was difficult task in some cases we spatulated it even extracoporeally, but still there was a chance of rotation and we found rotated PUJ in two of our failed pyeloplasties. We searched the literature and later on modified our technique of spatulation (10). The PUJ was dismembered partially, and then the ureter was spatulated on the lateral surface, as the ureter was still attached with pelvis, there was no chance of rotation, and also took initial sutures before dismember it completely. Using cutting needle is extremely valuable. In our first two cases, we used V-loc suture although suturing was easy, but we found it more traumatic so we stopped using V-loc suture. Operative time not only depends on the technique, but also on the experience of the surgeon. The operative time was longer than three hours in our initial cases where we dismembered PUJ completely before spatulation, but in our last 25 cases, the operative time was nearly two hours. So we suggest not dismembering PUJ completely before spatulation especially in initial cases. Using a cutting needle is also of utmost importance because it passes through the tissue easily and it is less traumatic also. 
Bilateral PUJ obstruction is relatively uncommon in adult population; we found in two patients, diagnosed during pregnancy in one, bilateral DJ stenting was done followed by successful laparoscopic repair, after the pregnancy was over. Intrarenal pelvis was found in seven patients; we used continuous suturing in all of them. The incidence of crossing vessels varied in the literature from 25 to 50\% (11); in our series, we found it in $18.86 \%$ of patients; lower pole crossing vessels could be saved in all except one. Simultaneous renal calculus was found in five patients and all were managed laparoscopically except in one. The incidence of conversion to open surgery was almost zero in most recent series (12), but in our series, conversion was required in 7.54\% of patients, all were from our initial 20 cases. In one patient, there were multiple small secondary calculi; in one, the PUJ looked normal; another patient was a case of secondary PUJ obstruction where dense fibrosis was present, dissection was difficult so converted; in another patient, there was intrarenal pelvis and already percutaneous nephrostomy was there in the lower calyx and there was lot of dense fibrosis so converted to open. In most recent series, the success rate of laparoscopic pyeloplasty has been comparable with open surgery. In our series, it is less, overall success rate was $85.71 \%$. Although Marco T.C. et al. (13) reported a success rate of $95.34 \%$ in their initial 53 cases whereas, Jarrett et al. (14) reported 96\% success rate in their initial 100 cases. In the literature, the rate of restenosis has been reported to be between 3.5\% and 4.8\% with the dismembered technique (15), however, in our series, it was higher (14.28\%) mainly because of difficulty in spatulation and suturing in initial cases which leads to excessive handling of the ureter. Thus, excessive handling of the ureter must be avoided while suturing to improve outcome of the surgery (16). In one of our failed patient, we found that the whole upper ureter was necrosed, probably due to faulty cautery machine which led to dissemination of the current inappropriately and excessive handling of the ureter. Now we do not use cautery near the PUJ, rather we use harmonic scalpel for dissection. Success rate is slightly less (85.71\%) in our series in comparison to other published series of initial cases of laparoscopic pyeloplasty $(13,14)$, and we think that it is mainly due to inappropriate technique during initial cases which led to excessive handling of the ureter, and after correcting our technique, we could achieve better success rate.

With the advent of robotic surgery, management of PUJ obstruction has been trending towards robot-assisted pyeloplasty. In 2008, Mufarrij et al. (17) conducted a study of 140 patients and concluded that robotic pyeloplasty using the da Vinci ${ }^{\circledR}$ system was safe, efficacious and durable for the management of both primary and secondary PUJ obstruction. The drawback of robotic pyeloplasty is the increased cost which was pointed out by Varda et al. (18) who concluded that robotic pyeloplasty was associated with higher cost as compared to laparoscopic and open pyeloplasty.

\section{Study Limitation}

The limitation of the study was that it is a descriptive study and the results have not been verified against a control group. Also it is a single-centre study and the results may be better interpreted via multi-centre trials.

\section{Conclusion}

Laparoscopic pyeloplasty is a minimally-invasive procedure and can be safely done without increasing the morbidity and complications. Although intracorporeal suturing is technically challenging especially in early cases, once these difficulties are overcome, the outcomes become comparable to open surgery. Open surgery is still considered to be the gold standard, but as urologists are getting trained more and more in laparoscopy, one day laparoscopic pyeloplasty will definitely replace open surgery as the gold standard treatment for the management of PUJ obstruction.

\section{Ethics}

Ethics Committee Approval: It was a retrospective study that didn't require the approval of the ethics committee.

Informed Consent: Informed consent was obtained from all patients.

Peer-review: Externally peer-reviewed.

\section{Authorship Contributions}

Concept: L.S., Design: L.S., Data Collection or Processing: M.B., Analysis or Interpretation: A.K., Literature Search: N.A., Writing: L.S.

Conflict of Interest: No conflict of interest was declared by the authors.

Financial Disclosure: The authors declare that they have no relevant financial.

\section{References}

1. Scardino PT, Scardino PL. Obstruction at the ureteropelvic junction. In: Bergman H, editor. The Ureter. 2nd ed. New York: Springer-Verlag; 1981;697.

2. Persky L, Krause JR, Boltuch RL. Initial complications and late results in dismembered pyeloplasty. J Urol. 1977;118:162-165.

3. Notley RG, Beaurgie JM. The long term follow-up of Anderson-Hynes pyeloplasty for hydronephrosis. Br J Urol. 1973;45:464-467.

4. Perksy L, Kraurse JR, Boltuch RL. Initial complications and late results in dismembered pyeloplasty. J Urol. 1977;118:162-165.

5. Motola JA, Badlani GH, Smith AD. Results of 212 consecutive endopyelotomies: an 8-year followup. J Urol. 1993;149:453-456. 
6. Nadler RB, Rao GS, Pearle MS, Nakada SY, Clayman RV. Acucise endopyelotomy: assessment of long-term durability. J Urol. 1996;156:10941097.

7. Brooks JD, Kavoussi LR, Preminger GM, Schuessler WW, Moore RG. Comparison of open and endourologic approaches to the obstructed ureteropelvic junction. Urology 1995;46:791-795.

8. Schuessler WW, Grune MT, Tecuanhuey LV, Preminger GM. Laparoscopic dismembered pyeloplasty. J Urol. 1993;150:1795-1799.

9. Eden CG, Cahill D, Allen JD. Laparoscopic dismembered pyeloplasty: 50 consecutive cases. BJU Int. 2001;88:526-531.

10. Mandhani A, Kumar D, Kumar A, Dubey D, Kapoor R. Steps to reduce operative time in laparoscopic dismembered pyeloplasty for moderate to large renal pelvis. Urology. 2005;66:981-984.

11. Park JM, Bloom DA. The pathophysiology of ureteropelvic junction obstruction. Urol Clin North Am. 1998;25:161-169.

12. Başataç C, Boylu U, Önol FF, Gümüş E. Comparison of surgical and functional outcomes of open, laparoscopic and robotic pyeloplasty for the treatment of ureteropelvic junction obstruction. Turk J Urol. 2014;40:24-30.
13. Lasmar MTC, Castro Junior HA, Vengjer A, Guerra FAT, Souza EAC, Rocha ML. Transperitoneal Laparoscopic Pyeloplasty: Brazilian Initial Experience with 55 Cases, international Braz J Urol. 2010;36: 678-684.

14. Jarrett TW, Chan DY, Charambura TC, Fugita O, Kavoussi LR. Laparoscopic pyeloplasty: the first 100 cases. The Journal of urology. 2002;167:12531256.

15. Rassweiler JJ, Teber D, Frede T. Complications of lapa- roscopic pyeloplasty. World J Urol. 2008;26:539-547.

16. Radfar MH, Afyouni A, Shakiba B, Hamedanchi S, Zare A. A New Touchless Technique for Suturing in Transperitoneal Laparoscopic Pyeloplasty. J Laparoendosc Adv Surg Tech A. 2019;29:519-522.

17. Mufarrij PW, Woods $M$, Shah OD, Palese MA, Berger AD, Thomas R, Stifelman MD. Robotic dismembered pyeloplasty: a 6-year, multi-institutional experience. J Urol. 2008;180:1391-1396.

18. Varda BK, Johnson EK, Clark C, Chung BI, Nelson CP, Chang SL. National Trends of Perioperative Outcomes and Costs for Open, Laparoscopic and Robotic Pediatric Pyeloplasty. J Urol. 2014;191:1090-1096. 